\title{
Industrial safety and health actions for business growth in a metalworking industry
}

\section{Acciones de seguridad e higiene industrial para el crecimiento empresarial en una industria del ramo metalmecánica}

NAVA-MORALES, Francisca $\dagger^{*}$, ALVA-GALLEGOS, Rodrigo, FLORES-GALVÁN, Francisco Ángel and BALTAZAR-PLATA, Carlos Gustavo

Universidad Tecnológica del Valle de Toluca, Carretera, Del Depto del Distrito Federal km 7.5, 52044 Santa María Atarasquillo, Méx.

ID $1^{\text {st }}$ Author: Francisca, Nava-Morales / ORC ID: 0000-0001-8931-6770, CVU CONACYT ID: 507130

ID $1^{\text {st }}$ Coauthor: Rodrigo, Alva-Gallegos / ORC ID: 0000-0001-9434-4610

ID $2^{\text {nd }}$ Coauthor: Francisco Ángel, Flores-Galván / ORC ID: 0000-0002-9354-2006, CVU CONACYT ID: 333455

ID $3^{\text {rd }}$ Coauthor: Carlos Gustavo, Baltazar-Plata / ORC ID: 0000-0003-4131-7138

DOI: $10.35429 /$ EJRS.2019.8.5.23.31

Received February 10, 2019; Accepted June 19, 2019

Abstract

Objectives. Improve the working conditions and productivity index through the implementation of Industrial Safety and Hygiene and Plant Distribution actions in a pressure foundry company. Methodology. 1. Analysis of the manufacturing process of aluminum and zamak parts. 2. To identify the risk elements those do not allow to work in a safe and a right way. 3. To assign safety equipment according to the risks of the area and the integration of a Joint Commission on Safety and Industrial Hygiene. 4. To identify the containers for waste management in the different phases of the process. 5. To re-distribute the lay out to improve ventilation and lighting of the areas. 6. To analyze the results, considering the impact on the improvement of the company's productivity. Contribution. Ensure the safety of its employees, achieve a better work environment, comply with established regulations and improve productivity in the company.

\section{Resumen}

Objetivos. Mejorar condiciones de trabajo e índices de productividad mediante la implementación de acciones de Seguridad e Higiene Industrial y Distribución de Planta en una empresa de fundición a Presión. Metodología. 1. Análisis del proceso de fabricación de piezas de aluminio y zamak. 2. Identificación de los riesgos de trabajo en las distintas áreas de fabricación para determinar cuáles son los elementos que pueden impedir que las actividades de trabajo se lleven a cabo de forma óptima y segura. 3. Asignar de equipos de protección personal de acuerdo a los riesgos del área y la integración de una Comisión Mixta de Seguridad e Higiene Industrial. 4. Identificar de contenedores para el manejo de residuos en las diferentes fases del proceso. 5. Redistribución de Planta para mejorar la ventilación e iluminación de las áreas de trabajo. 6 . Analizar de resultados, considerando el impacto en la mejora de la productividad de la empresa. Contribución. Garantizar la seguridad de sus colaboradores, lograr un mejor ambiente de trabajo, cumplir con la normatividad establecida y mejorar la productividad en la empresa.

Seguridad, Condiciones, Mejora

Citation: NAVA-MORALES, Francisca, ALVA-GALLEGOS, Rodrigo, FlORES-GALVÁN, Francisco Ángel and BALTAZAR-PLATA, Carlos Gustavo. Industrial safety and health actions for business growth in a metalworking industry. ECORFAN Journal-Republic of El Salvador. 2019. 5-8: 23-31.

\footnotetext{
* Correspondence to Author (email: francisca.nava@utvtol.edu.mx)

$\dagger$ Researcher contributing first author.
} 


\section{Introduction}

Today we know that, to meet the demands within the labor market, it is important that all organizations offer excellent quality in their products through continuous improvements in their processes without neglecting the safety of their workers, for that reason it is important that employees make proper use of Personal Protective Equipment that ensures their wellbeing. The company dedicated to the manufacture of aluminum and zamak parts through a casting and injection process, which over time has managed to expand its market nationally and internationally, which demands a constant work of continuous improvement within its processes, and a constant work of continuous improvement within its processes, being one of the primary ones related to Industrial Safety and Hygiene because, for every organization, the well-being of all its workers favors their best performance, bringing as benefits a Increased productivity as well as a better quality of the products offered, therefore it is necessary a correct application of Safety and Hygiene in the Industrial, and the change of some of the current working conditions.

In this company activities are carried out where workers are constantly exposed to suffer accidents or occupational diseases, due to the activities that are carried out, that is, they work with smelting furnaces and high temperature injection machines, with hydraulic dies, noise, vibrations, with sharp metals, gases and vapors from the foundry. However, something that is surprising is the lack and inappropriate use of personal protective equipment in each of the company's productive areas. For all the above, the aim is to improve working conditions, which have a direct impact on better productivity rates within the company.

On the other hand, many of the working conditions put employees at risk, mainly in the polishing area, this area is in a small room, without ventilation and with insufficient lighting where small metal particles from the sanding of the products are released, not having the personal protective equipment appropriate to the type of work, in addition the flow of materials is carried out on boxes or containers that are pulled, pushed and guided on concrete stairs, which presents for the people in charge of the movement of material a great work risk.
With respect to the garbage collection containers, they are not properly identified, that is, the garbage is not properly separated, any material or any waste is deposited in them, which has the consequence that this garbage cannot be deposited in municipal garbage dumps since Many times it contains hazardous materials. "The procedures, techniques and elements that are applied in the workplace, for the recognition, evaluation and control of harmful agents involved in work processes and activities, in order to establish measures and actions for accident prevention or occupational diseases, in order to preserve the life, health and physical integrity of workers, as well as avoid any possible deterioration to the workplace itself "[1] Camilo Janania Abraham.

\section{Process description}

The company is dedicated to the elaboration of aluminum and zamak parts, its process consists of six work stations to obtain the final product.

A detailed description of the activities carried out in each of the productive areas to obtain the final products with the characteristics required by customers will be made below.

\section{Casting (Obtaining Ingots)}

This process consists of melting the aluminum or zamak, for the manufacture of ingots, using reverber furnaces. The aluminum or zamak are placed in the oven and heated to obtain the aluminum or zamak in a liquid state. Aluminum melts at approximately $700^{\circ} \mathrm{C}$, while zamak melts at $400^{\circ} \mathrm{C}$. Subsequently, when the aluminum or zamak is in a liquid state, it is poured onto ingot molds (molds) that will make it take the desired shape, once this occurs it takes 10 to 15 seconds to solidify, when they cool they begin to unmold, in order to obtain the ingots that will later be used in the injection area.

\section{Casting-Injection}

This process begins when the ingots previously manufactured, are placed in a crucible that is installed on a furnace of refractory partition, this is heated to a temperature that is able to melt the aluminum or zamak respectively, that is, it returns to the liquid state. 
The aluminum or zamak can be poured into the injection machine that gives a shape to the product to be manufactured, by means of two molds that are compacted under hydraulic pressure, these have cavities that allow the passage of aluminum or liquid zamak, using a piston of push once it has solidified and adopted the new shape, the molds are opened, the piece is removed and placed on a work table.

\section{Die cut}

When the parts are injected, it is normal for the manufactured part to be left with surpluses of aluminum or zamak at its edges, which is why this workstation is responsible for giving the parts a better finish with the use of hydraulic dies and electric The removal of excess material is achieved through the use of molds that have the exact shape and size of the piece, this is placed in the mold, and a pedal is operated, this causes the other part of the mold to descend under pressure and remove excess contour material.

\section{Machining}

This is the workstation that is responsible for performing the relevant machining according to the piece to be made, all manufactured parts are different, and therefore each type has its own machining. All the pieces that have a surplus of material that could not be removed by the die cut, have to be polished, in other words, bank emery is used to completely remove the surpluses of any type of piece.

\section{Painting}

Most of the manufactured products are sold with their natural color, that is, they are not painted, to take advantage of their glossy finish, however, some products must meet other specifications, which is why this work area is so important Like the others In this area the powder paint is applied to the coating of the pieces, then they are placed in an electric oven, which produces a durable and high-strength finish, in addition to having no major impact on the environment.

\section{Packaging}

Once the pieces have gone through the entire manufacturing process complying with the specifications in particular, they are taken to the finished product area so that they can be packed in boxes according to customer requirements, sometimes the pieces are only counted and sent in sacks, this depends on the specifications indicated by the client. Each box carries an identification tag, with the name of the product, the date it was packed and the customer's name.

\section{Risk analysis}

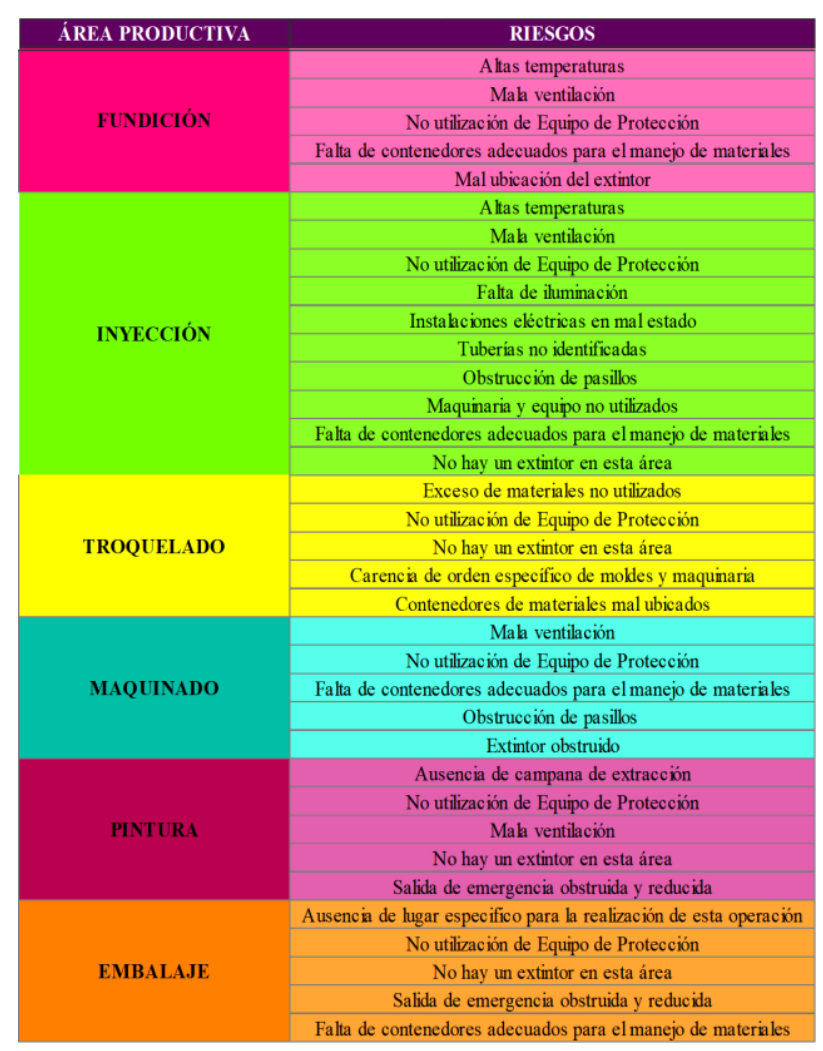

Table 1 Risk analysis

In the company a risk analysis is carried out in order to determine what are the reasons that can prevent work activities from being carried out optimally and safely. Table 1 shows the relationship of the types of risk in each of the productive areas.

With the results obtained after performing the risk analysis, it was determined that one of the main needs within the company is Safety and Industrial Hygiene. A survey of 50 workers was carried out to determine why they do not use their Protective Equipment, Table 2 lists the main reasons why workers do not use PPE. 


\begin{tabular}{|c|c|}
\hline RAZÓN & RESULTADO \\
\hline No proporcionan el equipo de protección personal & 23 \\
\hline Es incomodo & 14 \\
\hline Se tiene mucha experiencia sobre el trabajo & 9 \\
\hline Se perdió & 4 \\
\hline TOTAL & $\mathbf{5 0}$ personas \\
\hline
\end{tabular}

Table 2 Use of production equipment

\section{Assignment of protective equipment}

It is necessary to make a reference chart that allows a correct selection of personal protective equipment that should be used by each worker considering the activities performed and the environment in which it develops. Table 3 shows the classification of the equipment highlighting each part of the body that is exposed to work and the personal protective equipment that could be used, as well as a proposal on the personal protection equipment that should be delivered to each operator of according to their area and the work they do.

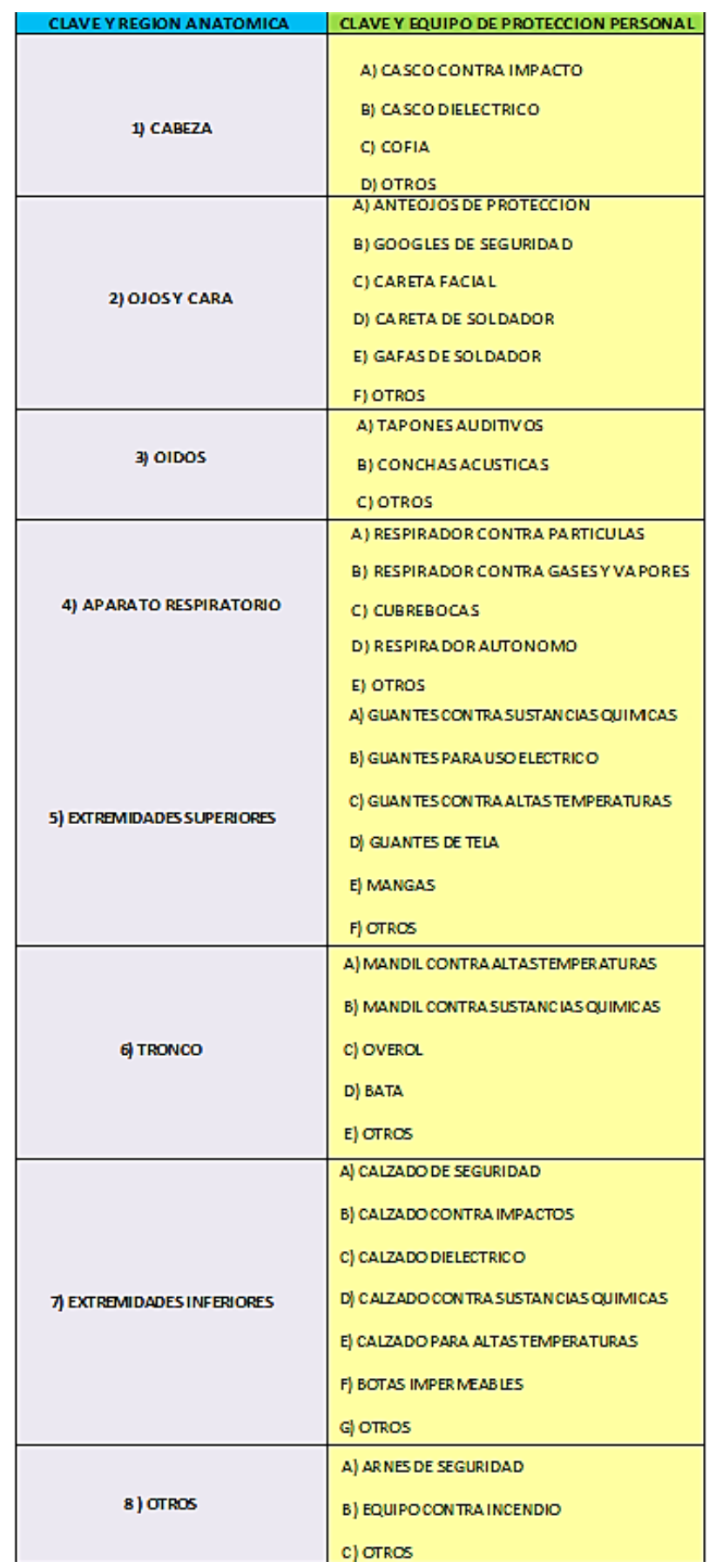

Table 3 EPP Type

The conditions of each worker depend on the area in which they work, that is, some workers are exposed to higher temperatures than others, some more are in contact with small metal particles that are inhaled or can affect the eyes etc., use Proper personal protective equipment prevents the worker from putting his health at risk. Table 4 which is a reference chart that proposes the personal protective equipment that should be used in each work area. 


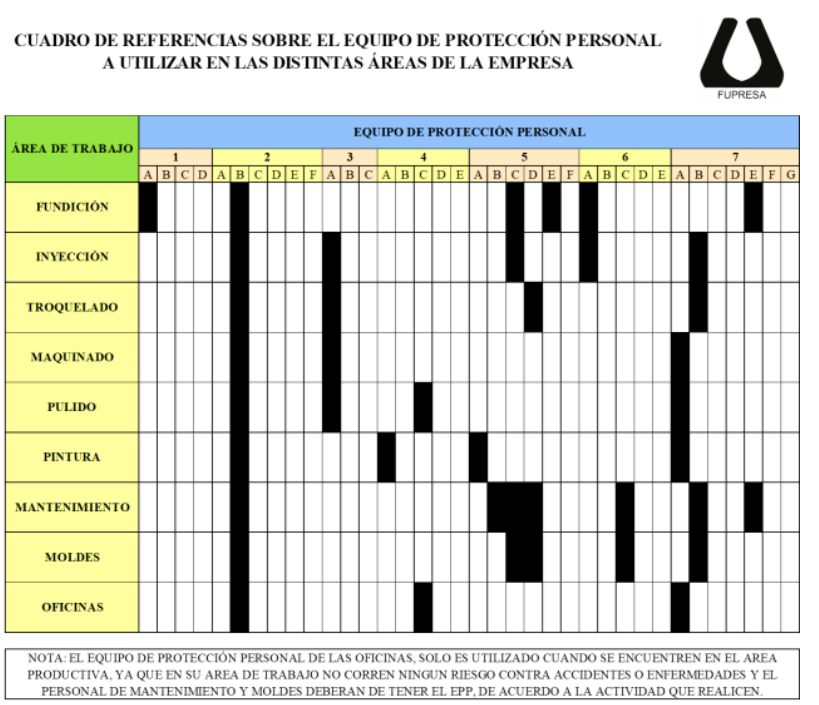

Table 4 Reference chart

The correct assignment of personal protective equipment will allow a better use of it, however, assigning protective equipment to workers is not enough, it is important that they also have the necessary information to know what it is and what is the importance of using the PPE. [2] Ramírez Cavassa César. In order to raise awareness among employees, as well as to provide them with sufficient information about the importance of the proper use of personal protective equipment, a triptych was drawn up that included necessary information about the importance of proper use of the equipment. personal protection, and of each of the parts of the body that you need to be protected to preserve the health and integrity of workers (Figure 1 and 2) The Joint Health and Safety Commission (CMSH) is also created, in order to verify that all workers wear their personal protective equipment, thus preventing accidents and occupational diseases.

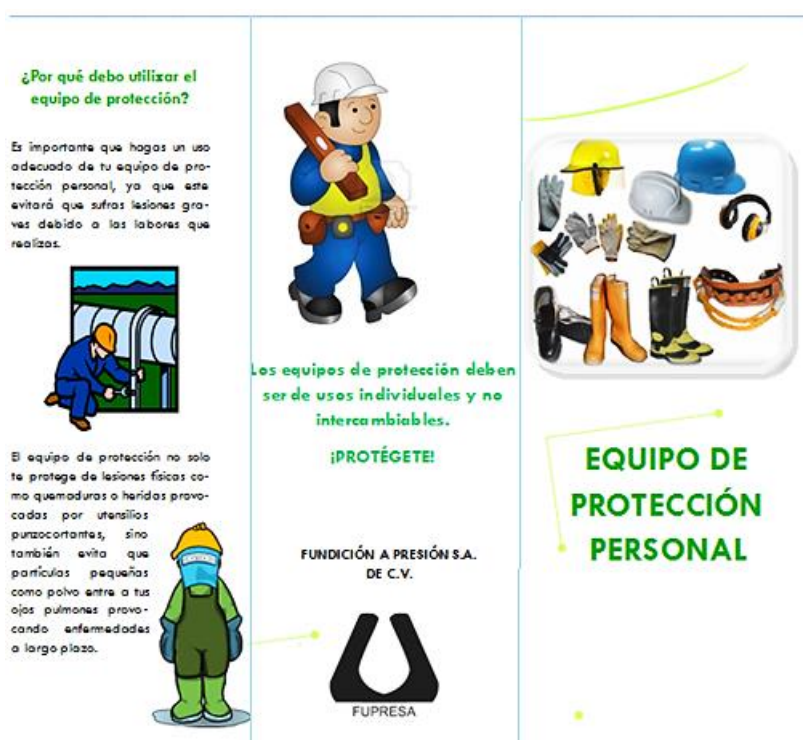

Figure 1 Triptych of Personal Protective Equipment

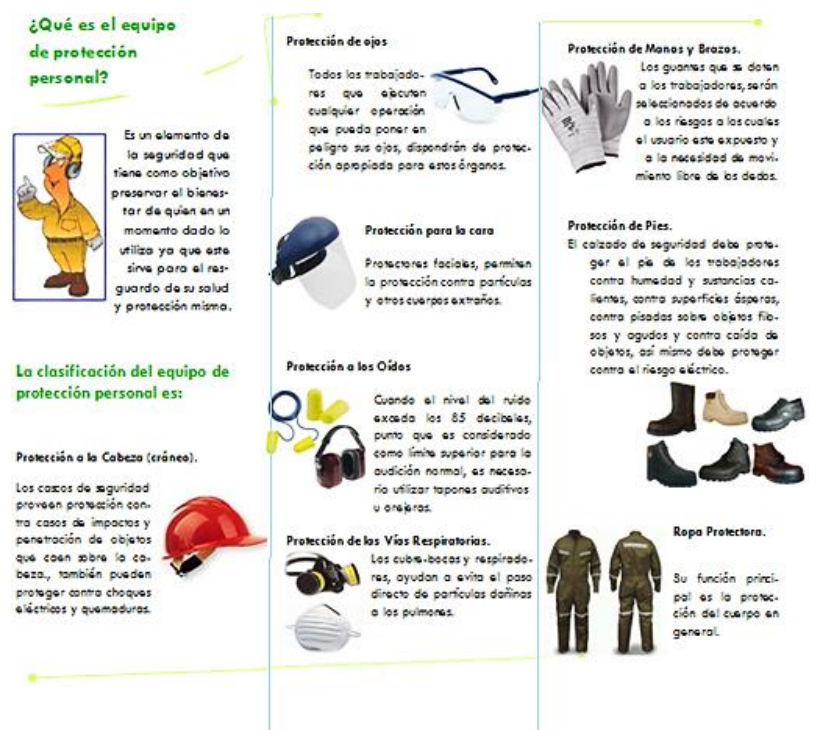

Figure 2 Triptych of Personal Protective Equipment

\section{Container identification}

The company presented serious problems with the garbage inside and outside the plant, that is, there were containers located in the different work areas, however, the workers did not deposit the garbage there or classify, when these containers were filled nobody moved them outside the plant and this caused problems of excessive dirt inside the company, coupled with this began to arise problems with the personnel who took the garbage; how:

- The personnel in charge of taking the garbage, had to separate it, and had to pay for that extra service.

- Waste such as sandpaper, rags, tows, gloves, mouth covers, earplugs, etc., could no longer be deposited in the garbage truck.

According to the above, a standardization of colors in the garbage containers was carried out, so that the classification of the same was easier for the workers, the standardization of the colors is as follows:

\section{Green - Organic \\ Yellow - Inorganic \\ Red - Hazardous waste}

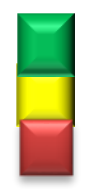

The colors used were chosen by the company, considering the needs they had and the expected results. Figure 3 shows the process of color standardization. 


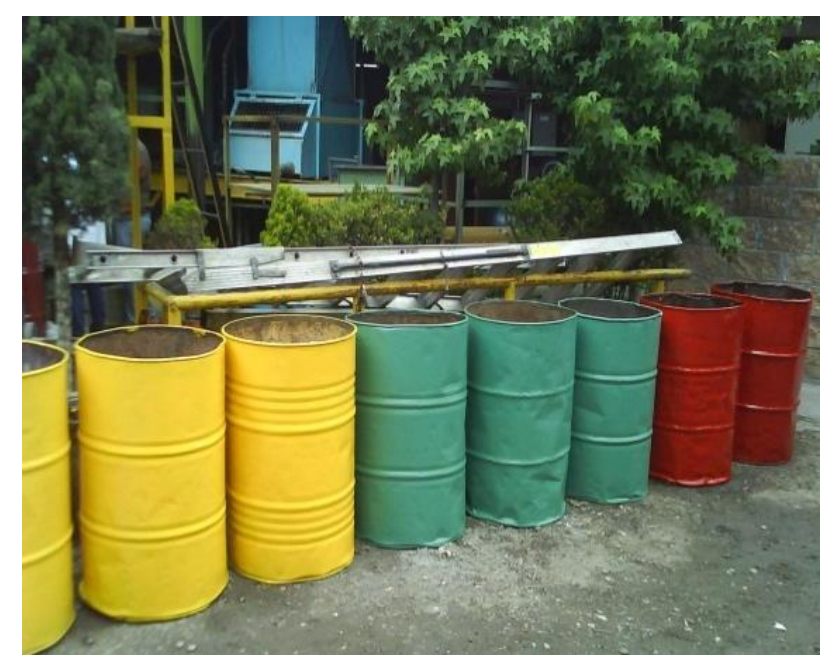

Figure 3 Standardization Process

The containers were placed in strategic areas inside and outside the plant, thus ensuring that workers deposit the garbage in the correct containers and assign personnel responsible for removing the containers located inside the plant when they are at their maximum capacity and of this how to keep work areas clean and tidy.

\section{Plant Redistribution}

Below is a description of the current plant distribution of the company and subsequently an improvement proposal will be made that allows the modification of work stations that do not have the right conditions, as well as making more efficient use of the productive area and Administrative of the plant.

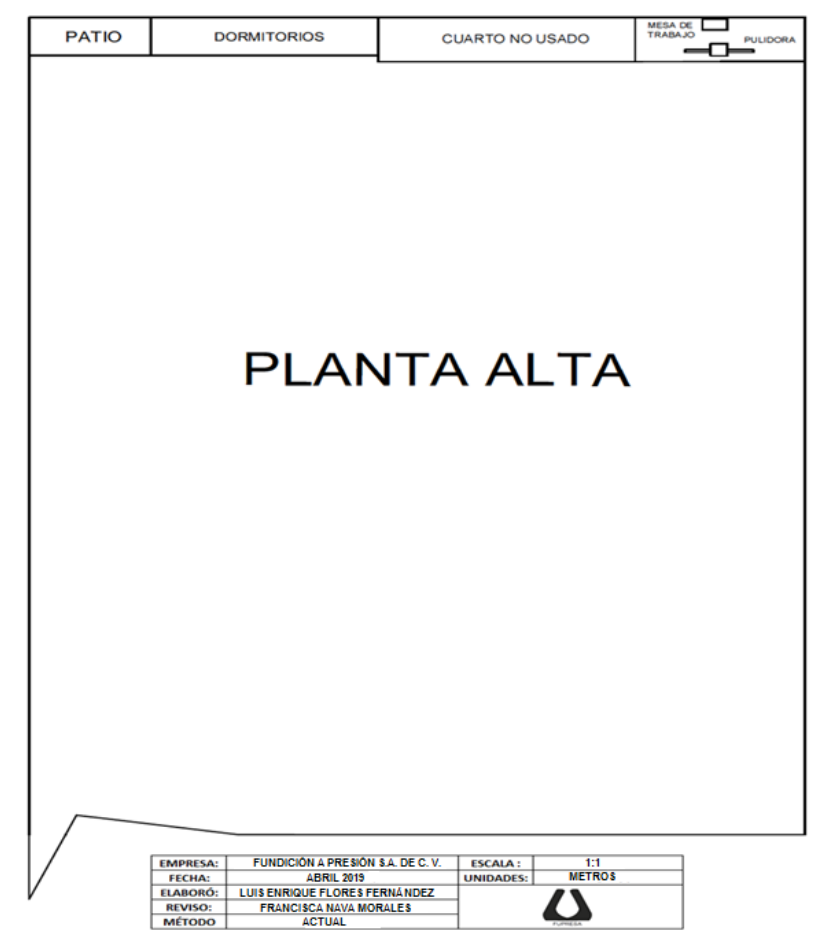

Figura 4 Upstairs distribution

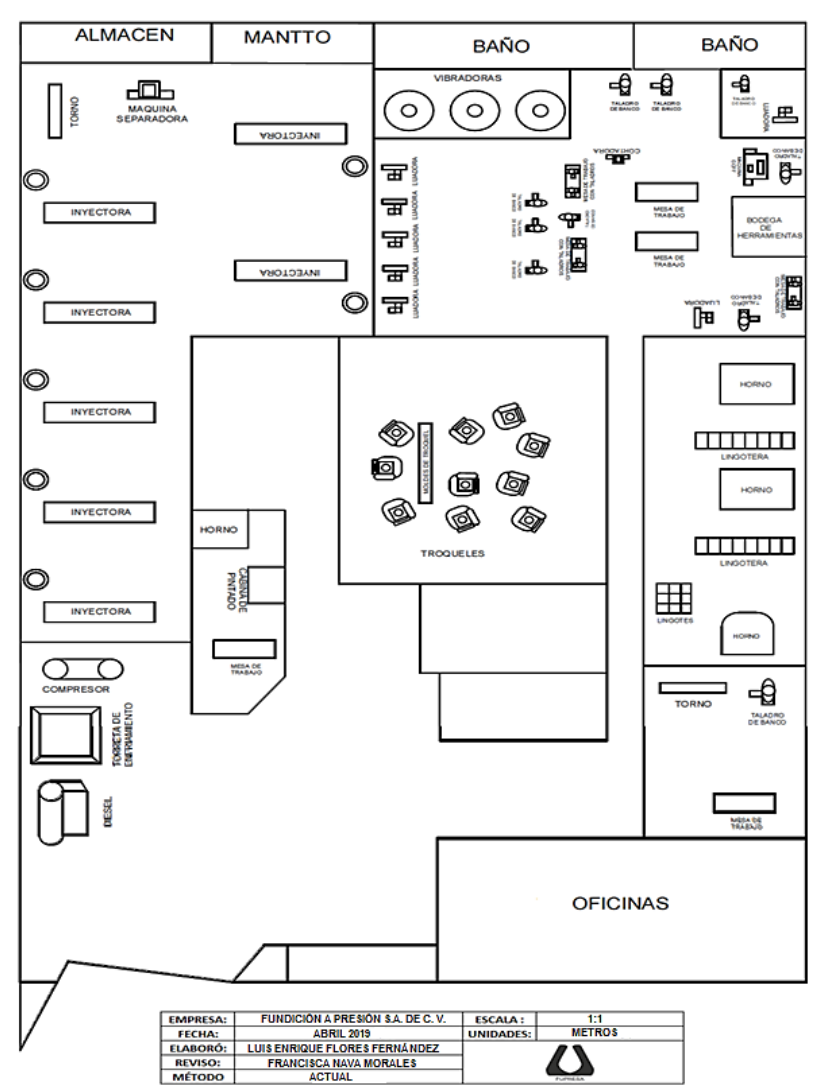

Figure 5 Ground Floor Distribution

\section{Current Distribution}

The department that presents problems with the ordering of its machinery and equipment is "machining", since the polishing area that is part of machining, is located on the top floor of the company, is a room with a dimension of $2.50 \mathrm{~m}$ $\mathrm{X} 2.25 \mathrm{~m}$, this causes small metal particles resulting from polishing the pieces to disperse throughout the place preventing proper lighting, in addition the place lacks windows that allow the passage of sunlight and ventilation.

The quantity of pieces that can be stored as a product in process are very few because the machines and other unused foreign elements occupy most of the available space, when it is required to distribute the material to this place the operators must tie a loop to the container to be able to pull it, push it or slide it down the concrete stairs, finally when the material has been worked the same situation happens, this type of working conditions can undermine the physical integrity of the operators, due to the risk of falling to the go up or down the stairs with such heavy containers. 
On the ground floor (fig. 5), there are other machines involved in the production process, the drills; They are used to make holes of various diameters according to the requirement of the piece, they do not have an adequate order within the area since they lack a good alignment, that is, each has a different position. On the left side of this area are the sanders and the containers of products in process, the last ones occupy too much space that could be used to correctly place all the machines and prevent the obstruction of the aisles as well as reduce the distance traveled by the materials to move on to the next phase of the process.

\section{Proposed Distribution}

According to the analysis performed in the machining area, the best distribution that can be had is in batches, that is, ordering the machinery according to the function it performs, firstly it is important that the bench drills are placed in only one direction, and that there is a prudent space between the work tables, thus allowing the correct transport of materials from one machine to another. The sanding machines must be on the opposite side of the drills in the same position, that is, glued to the wall, thus reducing the space used in this area.

With this distribution it will be possible to have more space in the place, which will facilitate the movement and transport of the materials either from one operation to the next or to some other area, in addition it will allow the correct placement of the other work tables, this with the purpose of having enough space for the polishing area to be installed on the ground floor, thus allowing the operator to perform their activities optimally, in addition a better flow of materials is achieved, that is, by not having to move to the upstairs the pieces to work the time it take to travel the material will decrease. In the vibrating machines, doors and concrete walls will be placed, that is, a completely enclosed room will be made that reduces the noise level, in addition the switches that actuate them will be placed on the outside, with this the operator can operate them without Need to be near the machine. Finally the containers of product in process, will be in the center of the machining area, allowing the materials to be transported and used effectively. Figure 6 and 7 is the graphic description of the distribution proposed in the company.

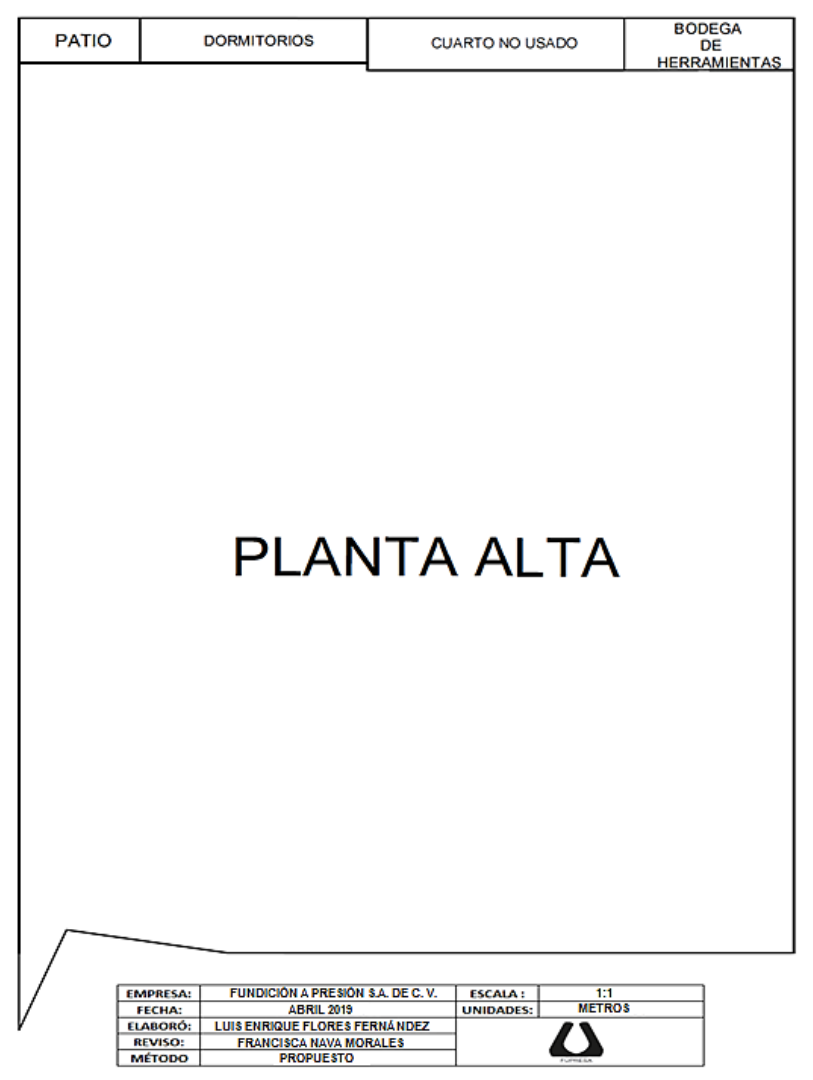

Figure 6 High floor distribution proposal

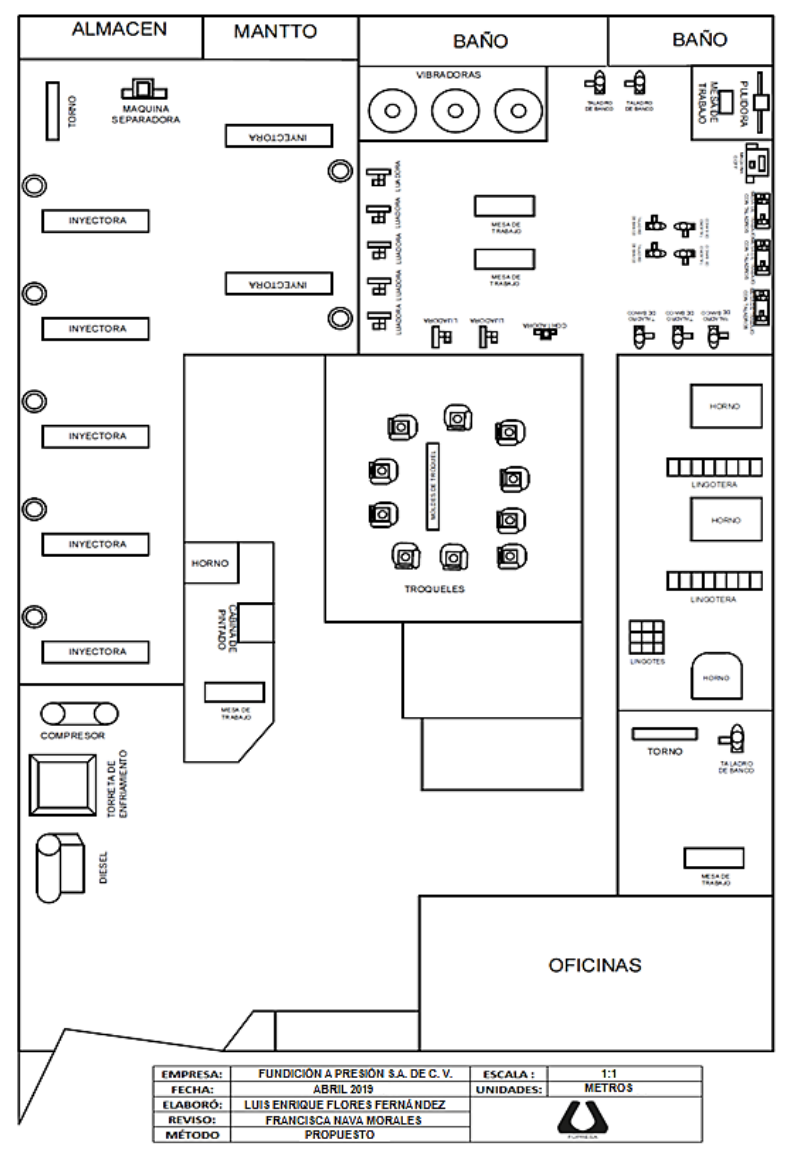

Figure 7 Ground floor distribution proposal 


\section{Results obtained}

The formats developed for the choice of protective equipment allowed the workers to adequately provide the type of equipment they require according to the area in which they develop, and the proper use of this prevents accidents and illnesses or occupational injuries caused by lack of protection against working conditions. With visual aids (Figure 8) and the active participation of the Joint Commission on Safety and Hygiene, it has been possible that each and every one of the company's employees make good use of their personal protection equipment during all their working days, at their Once the injuries caused by the lack of protection have decreased thanks to this.

\section{Protecciones Individuales YA QUE LAS TIENES}

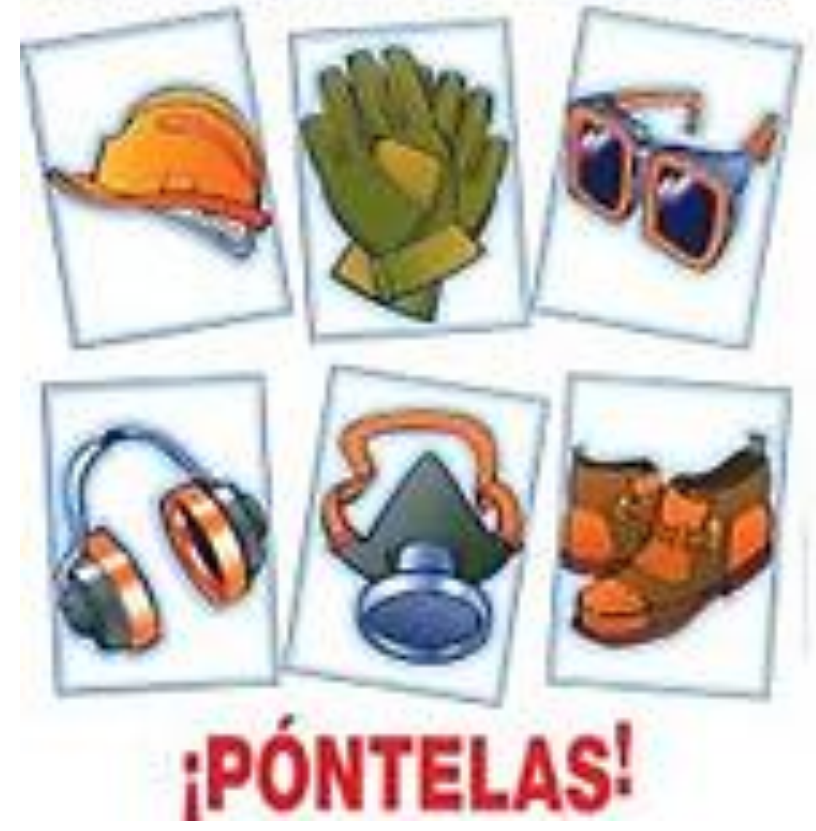

Figure 8 EPP visual aid

In addition, with the correct assignment of personal protective equipment within the company, it was possible to reduce the rate of occupational accidents caused by the conditions in which they worked, in addition to granting operators the protective equipment makes them feel safe to wear Out your activities. In order to get workers to make proper use of their protective equipment, it was necessary for the Joint Commission on Safety and Hygiene to participate constantly and respectfully to obtain good responses from employees.
With the correct identification of the boats, the handling of garbage and hazardous waste has been facilitated, since having a distinctive color for each type of waste it is possible to classify them quickly and effectively.

The plant distribution proposal will make the most of the space available within the company, at the same time, the flow of materials will be more efficient because having the machinery sorted according to their function, the material will circulate from one area to another efficiently since the aisles are well defined and free of any obstruction, the polishing area will be moved to the ground floor which will prevent the materials from having to go down and up several times, the tool cellar will be placed on the top floor with the purpose of making the most of the ground floor space. With the proposed plant redistribution, it will be possible to eliminate downtime between operations since the flow of materials will be more constant, that is, the time lost from one area to another may be better used, also considering that with this new distribution optimal use is made of the space available within the plant.

\section{Conclusions}

With the correct assignment of personal protective equipment within the company, the rate of occupational accidents caused by the conditions in which it was worked was reduced by $20 \%$, in addition to granting operators the protective equipment makes them feel sure to carry out their activities. In order to get workers to make proper use of their protective equipment, it was necessary for the Joint Commission on Safety and Hygiene to participate constantly and respectfully to obtain good responses from employees. With the redistribution of the plant, it will be possible to eliminate downtime between operations, since the flow of materials will be more constant, that is, the time lost from one area to another can be better used, also considering that with this new distribution optimal use is made of the space available within the plant.

Finally, the improvements implemented reflected allowed the company to raise productivity rates, since according to the analysis made, of one of its products (lemon squeezers), it was possible to increase production per day by $12 \%$. 


\section{References}

Camilo Janania Abraham, Ramírez Cavassa César $1^{\circ}$ ed., México. Edit., Limusa, 2007. $3^{\circ}$ Ed., México, Edit. Limusa, 2007.

Hicks E. Philip, Ingeniería Industrial y Administración, $2^{\circ}$ Edición, México, CECSA, 2006, 479 pp.

Manual de Seguridad e Higiene Industrial

Niebel Benjamín W. y Freivalds Andris, Ingeniería Industrial, Métodos, Estándares y diseño del Trabajo. $11^{\circ}$ Ed., México, Edit. McGraw Hill, 2004, 744 pp.

NOM-001-STPS-2008

NOM-004-STPS-2008

NOM-005-STPS-2017

NOM-021-STPS-2004

NOM-026-STPS-2008

NOM-113-STPS-2009.

Normatividad aplicable: Richard Muther, Distribución de Planta, $3^{\circ}$ Ed. México, Alfa omega, 1981, $472 \mathrm{pp}$.

Rodellar Lisa Adolfo, Seguridad e Higiene en el Trabajo, $1^{\circ}$ Ed., México, Edit. Alfa omega. 2002, 164 pp.

Seguridad Industrial. Un Enfoque Integral Ulrich Karl T. y Eppinger Steven D., Diseño y Desarrollo de Productos. Un Enfoque Multidisciplinario, $3^{\circ}$ Ed., México, Edit. Alfa omega. 2004, 366 pp. 